\title{
Synthesis of the Aglycone of the Shark Repellent Pavoninin-4 Using Remote Functionalization
}

\author{
Hua Gong and John R. Williams* \\ (Department of Chemistry, Temple University, Philadelphia, PA 19122-2585)
}

\section{Supporting Information}

\section{Experimental Section}

Flash column chromatography was performed on silica gel, grade 60 (230-400 mesh). Analytic thin layer chromatography (TLC) plates were visualized with phosphomolybdic acid. Melting points were determined on a capillary melting point apparatus and are uncorrected. IR spectra were recorded on a 4040 FT-IR spectrometer and the data reported in wavenumbers $\left(\mathrm{cm}^{-1}\right)$. The ${ }^{1} \mathrm{H}$ NMR and ${ }^{13} \mathrm{C}$ NMR spectra were recorded from a $400 \mathrm{MHz}$ spectrometer. Spectra were recorded in $\mathrm{CDCl}_{3}$ with chemical shift values in ppm relative to the solvent peak (7.26 for ${ }^{1} \mathrm{H}$ and 77.0 for $\left.{ }^{13} \mathrm{C}\right)$. Spectra of compound $\mathbf{1 0}$ were recorded in $\mathrm{CD}_{3} \mathrm{OD}$. Coupling constants are in units of Hertz. High resolution mass spectra (HRMS) were obtained on a double-focusing mass spectrometer.

(25R)-Cholest-5-ene-3 $\beta, 16 \beta, 26$-triol-3 $\beta, 26$-dipivaloate $(3 b)$. To a solution of triol $3 a^{1}$ (1 $\mathrm{g}, 2.4 \mathrm{mmol})$ in $20 \mathrm{~mL}$ THF and $10 \mathrm{~mL}$ pyridine was slowly added trimethylacetyl chloride $(1.0 \mathrm{~mL}, 8.0 \mathrm{mmol})$. The mixture was stirred at room temperature for $12 \mathrm{~h}$. Water was added and the mixture was extracted with EtOAc $(3 \times 15 \mathrm{~mL})$. The organic layers were dried over anhydrous $\mathrm{Na}_{2} \mathrm{SO}_{4}$, filtered, and concd under reduced pressure. Recrystallization of the residue with acetone afforded $\mathbf{3 b}$ as a white solid (1.75 g, 92\% yield): m.p. $=178-180^{\circ} \mathrm{C} ; \mathrm{IR}(\mathrm{KBr}): 3545,1728 \mathrm{~cm}^{-1} ;{ }^{1} \mathrm{H}$ NMR $\delta 0.82(\mathrm{~s}, 3 \mathrm{H}), 0.85-0.87$ 
$(\mathrm{d}, \mathrm{J}=6.7 \mathrm{~Hz}, 3 \mathrm{H}), 0.90-0.92(\mathrm{~d}, \mathrm{~J}=6.6 \mathrm{~Hz}, 3 \mathrm{H}), 1.03(\mathrm{~s}, 3 \mathrm{H}), 1.11(\mathrm{~s}, 9 \mathrm{H}), 1.13(\mathrm{~s}, 9 \mathrm{H})$, $3.74(\mathrm{~m}, 1 \mathrm{H}), 3.89(\mathrm{~m}, 1 \mathrm{H}), 4.25(\mathrm{~m}, 1 \mathrm{H}), 4.50(\mathrm{~m}, 1 \mathrm{H}), 5.29(\mathrm{~m}, 1 \mathrm{H}) ;{ }^{13} \mathrm{C} \mathrm{NMR} \delta 13.4$ $17.4,18.6,19.8,21.1,24.0,27.56,27.64,28.0,30.2,31.9,32.2,33.0,34.1,36.5,37.0$, $37.1,37.3,38.4,39.0,39.3,40.2,42.6,50.4,54.8,61.8,69.6,72.8,73.9,122.6,140.3$, 178.5, 179.1. HRMS calcd for $\mathrm{C}_{37} \mathrm{H}_{62} \mathrm{O}_{5}\left(\mathrm{M}+\mathrm{Na}^{+}\right)$609.4495, found 609.4486.

(25R)-Cholest-5-ene-3ß,26-diol (4). A solution of methanesulfonyl chloride (1 mL, 12.9 mmol) in dry pyridine $(10 \mathrm{~mL})$ was added to a soln of $\mathbf{3 b}(2.0 \mathrm{~g}, 3.41 \mathrm{mmol})$ in dry pyridine $(20 \mathrm{~mL})$ at $0^{\circ} \mathrm{C}$. The mixture was stirred at $0^{\circ} \mathrm{C}$ to room temperature for overnight. The red soln was poured into ice water and the resulting mixture was extracted with ether $(3 \times 20 \mathrm{~mL})$. The ether extract was washed successively with $2 \mathrm{~N}$ cold $\mathrm{HCl}$, brine, saturated $\mathrm{NaHCO}_{3}$, water, dried $\left(\mathrm{Na}_{2} \mathrm{SO}_{4}\right)$ and concentrated to give (25R)-cholest-5-

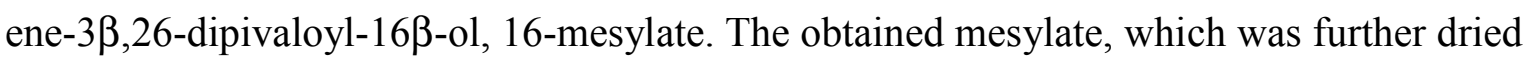
on high vacuum pump for several hours, was dissolved in $50 \mathrm{~mL}$ dry ether and was added dropwise to a mixture of excess LAH in $50 \mathrm{~mL}$ dry ether. The mixture was refluxed for 16 $\mathrm{h}$, cooled and decomposed first by the addition of a few drops of water ( $1 \mathrm{~mL} / 1 \mathrm{~g} \mathrm{LAH})$, followed by $10 \% \mathrm{NaOH}$ solution $(1 \mathrm{~mL} / 1 \mathrm{~g} \mathrm{LAH})$ and then water $(3 \mathrm{~mL} / 1 \mathrm{~g} \mathrm{LAH})$. The above mixture was left stirring at room temperature for $1 \mathrm{~h}$ and then filtrated through Celite. The filtrate was further dried over $\mathrm{Na}_{2} \mathrm{SO}_{4}$ and evaporated to afford the crude product (1.25 g, 90\% yield) as a white solid. Recrystallization from EtOAc yielded 26hydroxycholesterol 4 in 97\% purity (GC-MS analysis on the corresponding TMS ether ${ }^{2}$ ): m.p. $=168-170^{\circ} \mathrm{C}$, lit. $^{3}$ m.p. $=172-173^{\circ} \mathrm{C}$; IR (KBr): 3341, $2932 \mathrm{~cm}^{-1} ;{ }^{1} \mathrm{H}$ NMR $(5: 1$ $\left.\mathrm{CD}_{3} \mathrm{Cl}: \mathrm{CD}_{3} \mathrm{OD}\right) \delta 0.60(\mathrm{~s}, 3 \mathrm{H}), 0.82-0.83(\mathrm{~d}, \mathrm{~J}=6.7 \mathrm{~Hz}, 3 \mathrm{H}), 0.93(\mathrm{~d}, \mathrm{~J}=4.1 \mathrm{~Hz}, 3 \mathrm{H})$, 3.31-3.44 (m, 3H), $5.26(\mathrm{~m}, 1 \mathrm{H}) ;{ }^{13} \mathrm{C} \mathrm{NMR}\left(5: 1 \mathrm{CD}_{3} \mathrm{Cl}: \mathrm{CD}_{3} \mathrm{OD}\right) \delta$ 12.2, 16.8, 19.0, 19.7, 
$21.4,23.8,24.6,28.6,31.6,32.2,33.9,36.05,36.09,36.5,36.9,37.6,40.1,42.3,42.7$, $50.5,56.5,57.1,68.5,71.8,122.0,141.2$.

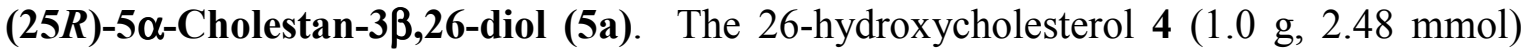
was dissolved in $20 \mathrm{~mL}$ methylenechloride and $30 \mathrm{~mL}$ of methanol. After adding a catalytic amount (ca. $60 \mathrm{mg}$ ) of Pd black, the flask was flushed three times with hydrogen. A hydrogen balloon was left atop of the flask in which the suspension was stirred for $4 \mathrm{~h}$. After the catalyst was removed by filtration, the solution was concd in vacuo to afford 1.0 $\mathrm{g}$ of the saturated diol 5a as a white solid (99\% yield). Further purification by recrystallization from EtOAc. m.p. $=172-173^{\circ} \mathrm{C}$; IR $(\mathrm{KBr}): 3341 \mathrm{~cm}^{-1} ;{ }^{1} \mathrm{H}$ NMR $\delta 0.51(\mathrm{~s}$, $3 \mathrm{H}), 0.66(\mathrm{~s}, 3 \mathrm{H}), 0.75-0.77(\mathrm{~d}, \mathrm{~J}=4.7 \mathrm{~Hz}, 3 \mathrm{H}), 0.77-0.78(\mathrm{~d}, \mathrm{~J}=4.8 \mathrm{~Hz}, 3 \mathrm{H}), 3.26-3.46$ $(\mathrm{m}, 3 \mathrm{H}) ;{ }^{13} \mathrm{C}$ NMR $\delta 12.5,12.7,16.9,19.0,21.7,23.8,24.6,29.1,31.9,32.5,33.9,35.9$, $36.1,37.4,38.6,40.5,43.0,45.3,54.8,56.7,56.9,69.0,71.8$; HRMS calcd for $\mathrm{C}_{27} \mathrm{H}_{48} \mathrm{O}_{2}$ $\left(\mathrm{M}+\mathrm{H}-\mathrm{H}_{2} \mathrm{O}^{+}\right)$387.3630, found 387.3627 .

(25R)-5 $\boldsymbol{\alpha}$-Cholestan-3ß,26-diol 26-pivaloate (5b). To a soln of the diol 5a (100 mg, 0.25 mmol) and 3-pivaloyl-1,3-thiazolidine-2-thione 6 (70 $\mathrm{mg}, 0.35 \mathrm{mmol})$, which was made from thiazolidine-2-thione, ${ }^{4}$ in $8 \mathrm{~mL}$ dry THF was added sodium hydride $(60 \%$ in mineral oil, $18 \mathrm{mg}, 0.45 \mathrm{mmol}$,) at room temperature. The resulted soln was stirred under argon at room temperature for $12 \mathrm{~h}$. Water was added and the mixture was extracted with EtOAc (3 x $10 \mathrm{~mL}$ ). The organic layers were washed with saturated ammonium chloride solution, water, and then dried over $\mathrm{Na}_{2} \mathrm{SO}_{4}$, filtered, and concd under reduced pressure. The crude oil product was purified by flash column chromatography (silica gel, 5:1 hexanes/EtOAc) to afford $\mathbf{5 b}$ as colorless oil (98 mg, $80 \%$ yield). IR (KBr): $3378,1728 \mathrm{~cm}^{-1} ;{ }^{1} \mathrm{H}$ NMR $\delta$ 
$0.57(\mathrm{~s}, 3 \mathrm{H}), 0.73(\mathrm{~s}, 3 \mathrm{H}), 0.82-0.83(\mathrm{~d}, \mathrm{~J}=6.6 \mathrm{~Hz}, 3 \mathrm{H}), 0.84-0.86(\mathrm{~d}, \mathrm{~J}=6.8 \mathrm{~Hz}, 3 \mathrm{H})$, $1.13(\mathrm{~s}, 9 \mathrm{H}), 3.50(\mathrm{~m}, 1 \mathrm{H}), 3.77-3.86(\mathrm{~m}, 1 \mathrm{H}) ;{ }^{13} \mathrm{C} \mathrm{NMR} \delta 12.5,12.7,17.3,19.0,21.7$, 23.6, 24.6, 27.6, 27.7, 28.7, 29.1, 31.9, 32.5, 33.0, 34.2, 35.9, 36.1, 36.5, 37.4, 38.6, 39.3, $40.4,43.0,45.3,54.8,56.6,56.9,69.7,71.8,179.1$; HRMS calcd for $\mathrm{C}_{32} \mathrm{H}_{56} \mathrm{O}_{3}\left(\mathrm{M}+\mathrm{Na}^{+}\right)$ 511.4127, found 511.4117.

(25R)-5 $\alpha$-Cholestan-3 $\alpha$-((-4-benzoyl)phenylacetyloxy)-26-ol 26-pivaloate (8). To a stirring solution of the alcohol $\mathbf{5 b}(200 \mathrm{mg}, 0.41 \mathrm{mmol})$ in dry $\mathrm{THF}(10 \mathrm{~mL})$ at $25^{\circ} \mathrm{C}$ was added triphenylphosphine $(236 \mathrm{mg}, 0.90 \mathrm{mmol})$ and the carboxylic acid 7 (138 $\mathrm{mg}, 0.57$ mmol $){ }^{5}$ followed by the dropwise addition of DEAD $(141 \mu \mathrm{L}, 0.90 \mathrm{mmol})$ and the reaction was stirred for $1 \mathrm{~h}$. Water was added and the mixture was extracted with ether (3 x $10 \mathrm{~mL}$ ). The combined organic extracts were dried over anhydrous $\mathrm{Na}_{2} \mathrm{SO}_{4}$, filtered, and concd under vacuum. Flash column chromatography of the crude residue (silica gel, 5:1 hexanes/EtOAc) provided the benzophenone ester 8 (254 mg, 87\% yield) as colorless oil. IR (KBr): 1734, $1647 \mathrm{~cm}^{-1} ;{ }^{1} \mathrm{H}$ NMR $\delta 0.54(\mathrm{~s}, 3 \mathrm{H}), 0.67(\mathrm{~s}, 3 \mathrm{H}), 0.80-0.81(\mathrm{~d}, \mathrm{~J}=6.5 \mathrm{~Hz}$, 3H), 0.83-0.84 (d, J = 6.7 Hz, 3H), $1.11(\mathrm{~s}, 9 \mathrm{H}), 3.61(\mathrm{~s}, 2 \mathrm{H}), 3.76-3.84(\mathrm{~m}, 2 \mathrm{H}), 4.94(\mathrm{~s}$, 1H), 7.32-7.71 (m, 9H); ${ }^{13} \mathrm{C}$ NMR $\delta 11.7,12.5,14.6,17.3,19.1,21.2,23.6,24.5,26.5$, 27.6, 27.7, 28.7, 32.4, 33.0, 33.2, 33.3, 34.2, 35.8, 36.1, 36.5, 39.3, 40.4, 41.8, 42.4, 43.0, $54.7,56.6,56.9,69.5,69.7,69.9,71.5,128.7,129.7,130.3,130.4,130.8,130.9,132.7$, 136.6, 138.1, 139.8, 170.6, 179.0, 196.6. HRMS calcd for $\mathrm{C}_{32} \mathrm{H}_{56} \mathrm{O}_{3}\left(\mathrm{M}+\mathrm{Na}^{+}\right)$733.4808, found 733.4823 .

(25R)-5 $\alpha$-Cholestan-3 $\alpha, 15 \alpha, 26-$ triol (10). The solution of (25R)-5 $\alpha$-Cholestan-3 $\alpha-((-4-$ benzoyl)phenylacetyloxy)-26-ol 26-pivaloate (8) $(100 \mathrm{mg}, 0.14 \mathrm{mmol})$ in $140 \mathrm{~mL}$ 
anhydrous benzene was degassed for $1 \mathrm{~h}$ with purified argon. The solution was photolyzed for $1.5 \mathrm{~h}$ with a 450-W medium-pressure Hanovia lamp through a Pyrex filter. The solvent was removed and the crude oil was dissolved in $25 \% \mathrm{KOH}(2 \mathrm{~mL})$, ethanol $(4 \mathrm{~mL})$ and THF ( $2 \mathrm{~mL})$ and the mixture was refluxed for $2 \mathrm{~h}$. Water was added and the mixture was extracted with ether $(3 \times 10 \mathrm{~mL})$. The combined organic extracts were dried over $\mathrm{Na}_{2} \mathrm{SO}_{4}$, filtered, and concd under reduced pressure to give a pale yellow solid. The crude olefinic diol was dissolved in pyridine $(5 \mathrm{~mL})$ at $25^{\circ} \mathrm{C}$ and excess acetic anhydride was added and the mixture was stirred overnight. Water was added and the mixture was extracted with ether $(3 \times 5 \mathrm{~mL})$. The combined organic extracts were dried over $\mathrm{Na}_{2} \mathrm{SO}_{4}$, filtered, and concentrated under reduced pressure. Flash column chromatography (silica gel, 10:1 hexanes/EtOAc) of the crude solid gave a mixture of the olefinic diacetate 9a and the saturated diacetate $9 \mathrm{~b}$ (45 mg, 65\% combined yield). To a stirred solution of the mixture of $9 \mathbf{a}$ and $9 \mathbf{b}$ in dry THF $(3 \mathrm{~mL})$ was added gradually a solution of $\mathrm{BH}_{3}$.THF $(1.0 \mathrm{~mL}, 1.5$ mmol), and the mixture was stirred at $50^{\circ} \mathrm{C}$ for $2 \mathrm{~h}$ under a stream of argon. The solution was cooled with ice bath, absolute ethanol $(1 \mathrm{~mL}), 3 \mathrm{~N} \mathrm{NaOH}(1 \mathrm{~mL})$ and $30 \% \mathrm{H}_{2} \mathrm{O}_{2}(1$ $\mathrm{mL}$ ) were successively added. The reaction mixture was refluxed for $1 \mathrm{~h}$, concentrated in vacuo to remove the excess THF, and extracted with ethyl acetate $(3 \times 5 \mathrm{~mL})$. The organic phase was dried $\left(\mathrm{Na}_{2} \mathrm{SO}_{4}\right)$, filtered and concentrated in vacuum. The residue was flashchromatographed to afford $\mathbf{1 0}$ as a white solid (19 $\mathrm{mg}, 33 \%$ yield from $\mathbf{8}$, about $11 \mathrm{mg}$

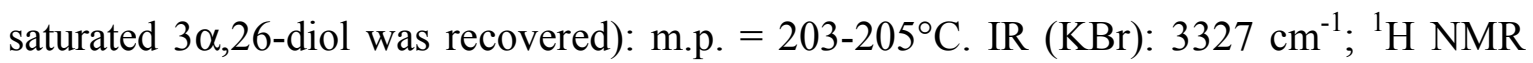
$\left(\mathrm{CD}_{3} \mathrm{OD}\right) \delta 0.69(\mathrm{~s}, 3 \mathrm{H}), 0.81(\mathrm{~s}, 3 \mathrm{H}), 0.87-0.89(\mathrm{~d}, \mathrm{~J}=5.6 \mathrm{~Hz}, 3 \mathrm{H}), 0.91-0.92(\mathrm{~d}, \mathrm{~J}=4.4$ $\mathrm{Hz}, 3 \mathrm{H}), 3.26-3.39(\mathrm{~m}, 2 \mathrm{H}), 3.80(\mathrm{dt}, \mathrm{J}=9.1,3.0 \mathrm{~Hz}, 1 \mathrm{H}), 3.94(\mathrm{~m} 1 \mathrm{H}) ;{ }^{13} \mathrm{C} \mathrm{NMR}$ $\left(\mathrm{CD}_{3} \mathrm{OD}\right) \delta 10.6,12.6,15.9,17.9,20.6,23.2,28.4,28.7,32.3,32.4,33.6,35.4,35.5,35.6$, 
35.7, 36.0, 36.2, 39.0, 40.5, 40.7, 43.7, 53.9, 54.7, 63.0, 66.0, 67.4, 73.1; HRMS calcd for $\mathrm{C}_{27} \mathrm{H}_{48} \mathrm{O}_{3}\left(\mathrm{M}+\mathrm{H}-\mathrm{H}_{2} \mathrm{O}^{+}\right)$403.3576, found 403.3572.

(25R)-5 $\alpha$-Cholestan-3 $\alpha, 15 \alpha, 26$-triol 26-acetate (1a). To a solution of 10 (50 mg, 0.12 mmol) in $2 \mathrm{~mL}$ THF and $5 \mathrm{~mL}$ vinyl acetate was added 1,3-dichlorodistannoxane (1.2 mg, $\left.2.2 \times 10^{-3} \mathrm{mmol}\right)$. The mixture was stirred at room temperature for $12 \mathrm{~h}$. After evaporation, the crude mixture was chromatographed on a silica gel column (5:1 hexanes/EtOAc) to afford 1a (44 mg, 80\% yield) as colorless oil. IR (KBr): 3415, $1721 \mathrm{~cm}^{-1} ;{ }^{1} \mathrm{H}$ NMR $\delta 0.62$ (s, 3H), $0.73(\mathrm{~s}, 3 \mathrm{H}), 0.82-0.83(\mathrm{~d}, \mathrm{~J}=6.8 \mathrm{~Hz}, 3 \mathrm{H}), 0.83-0.84(\mathrm{~d}, \mathrm{~J}=6.8 \mathrm{~Hz}, 3 \mathrm{H}), 1.99$ (s, $3 \mathrm{H}), 3.75-3.88(\mathrm{~m}, 3 \mathrm{H}), 3.97-3.98(\mathrm{~m}, 1 \mathrm{H}) ;{ }^{13} \mathrm{C} \mathrm{NMR} \delta 11.7,13.8,17.2,18.9,21.1,21.5$, $23.5,28.8,29.4,32.6,32.8,32.9,34.1,35.5,35.6,36.3,36.3,36.5,39.3,40.6,40.9,44.5$, 54.0, 54.6, 64.3, 66.9, 67.0, 74.3, 171.8; HRMS calcd for $\mathrm{C}_{29} \mathrm{H}_{50} \mathrm{O}_{4}\left(\mathrm{M}+\mathrm{Na}^{+}\right)$485.3607, found 485.3617 .

\section{References}

1. Williams, J. R.; Chai, D.; Bloxton II, J. D.; Gong, H.; Solvible, W. R. Tetrahedron, 2003, 59, 3183.

2. GC-MS analysis was provided by Dr. J. Goodman at University of Kentucky.

3. Varma, R. K.; Koreeda, M.; Yagen, B.; Nakanishi, K.; Caspi, E. J. Org. Chem., 1975, $40,3680$.

4. Yamada, S. J. Org. Chem. 1992, 57, 1591.

5. Zderic, J. A.; Kubitschek, M. J.; Bonner, W. A. J. Org. Chem. 1961, 26, 1635. 


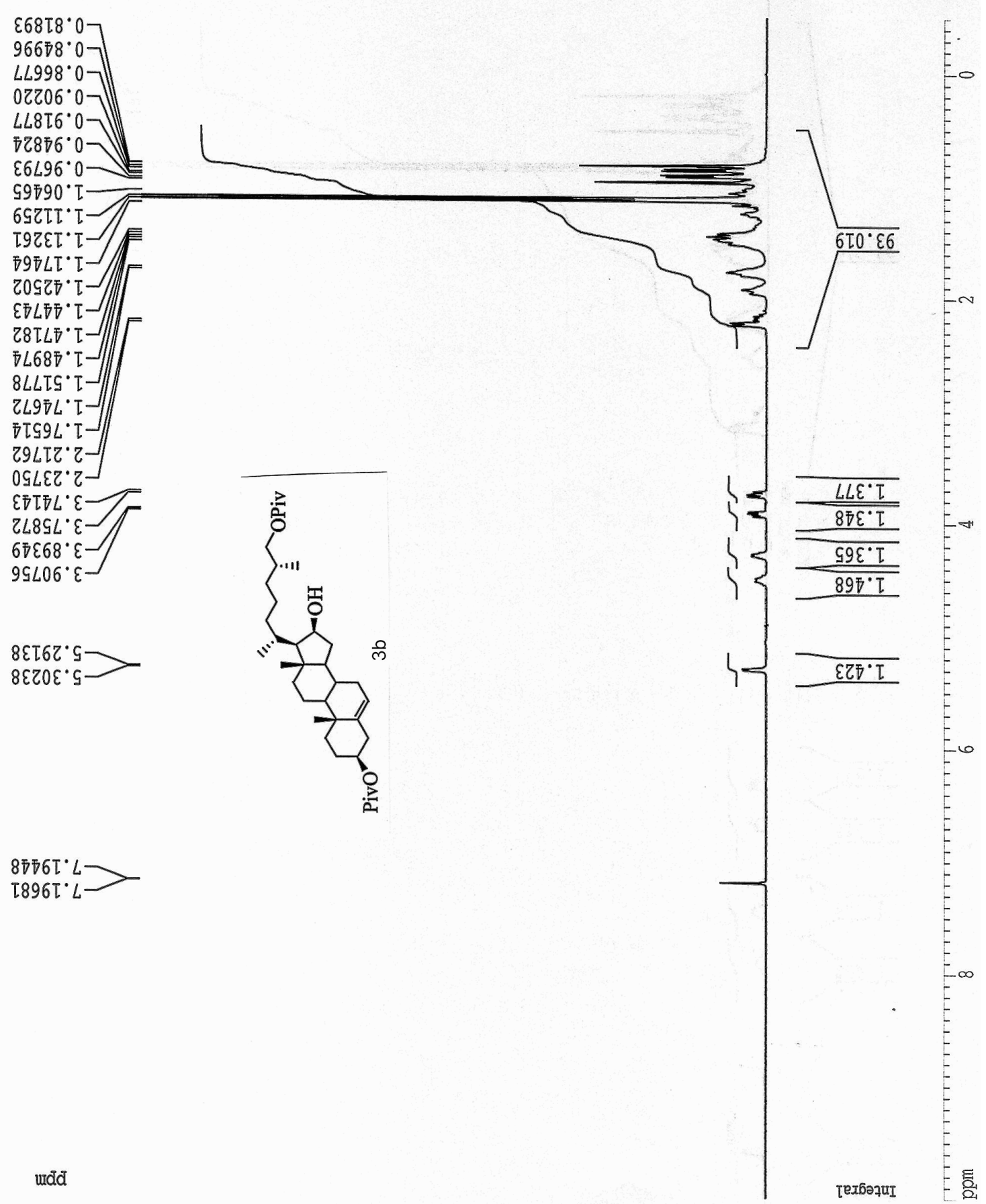




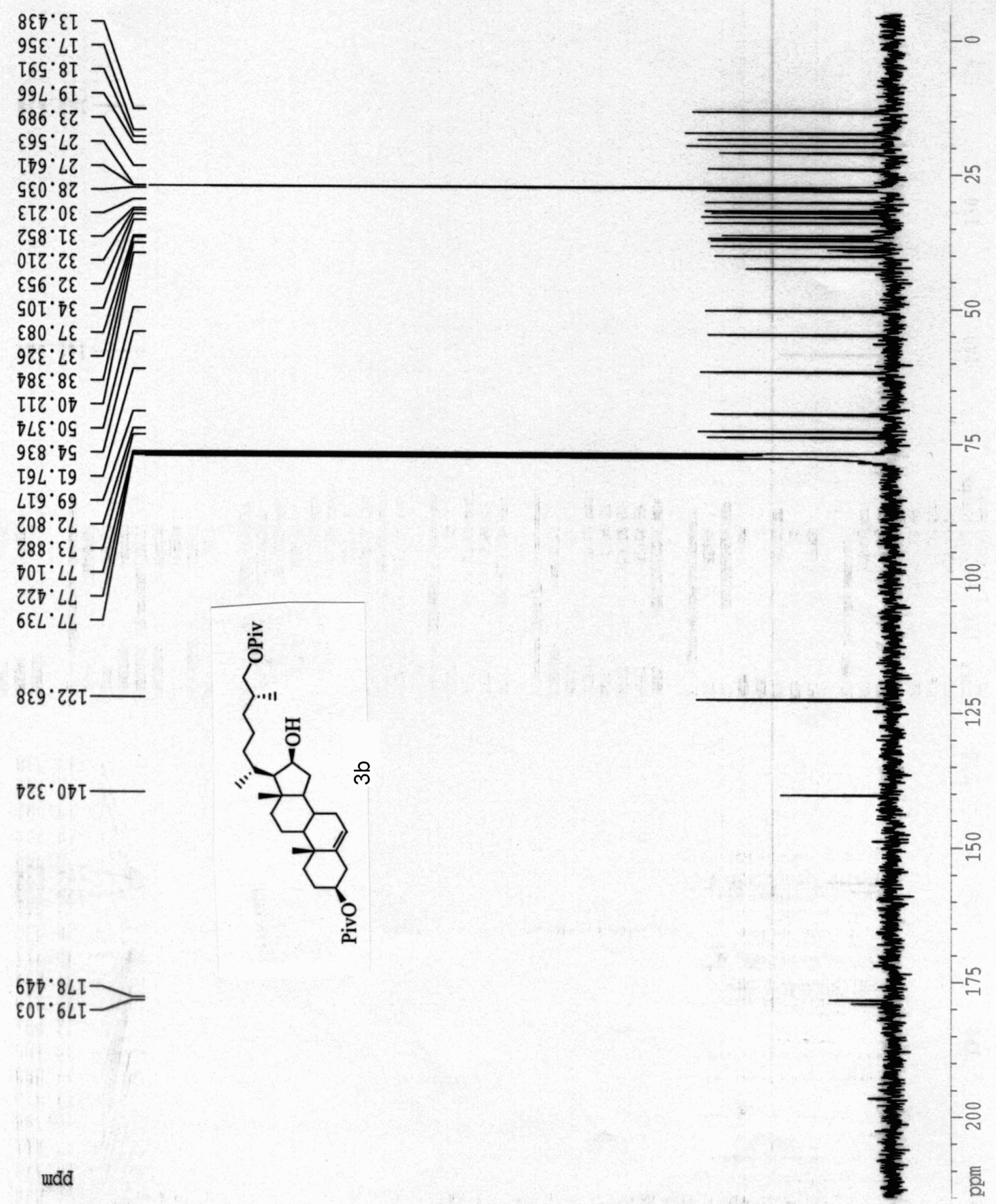




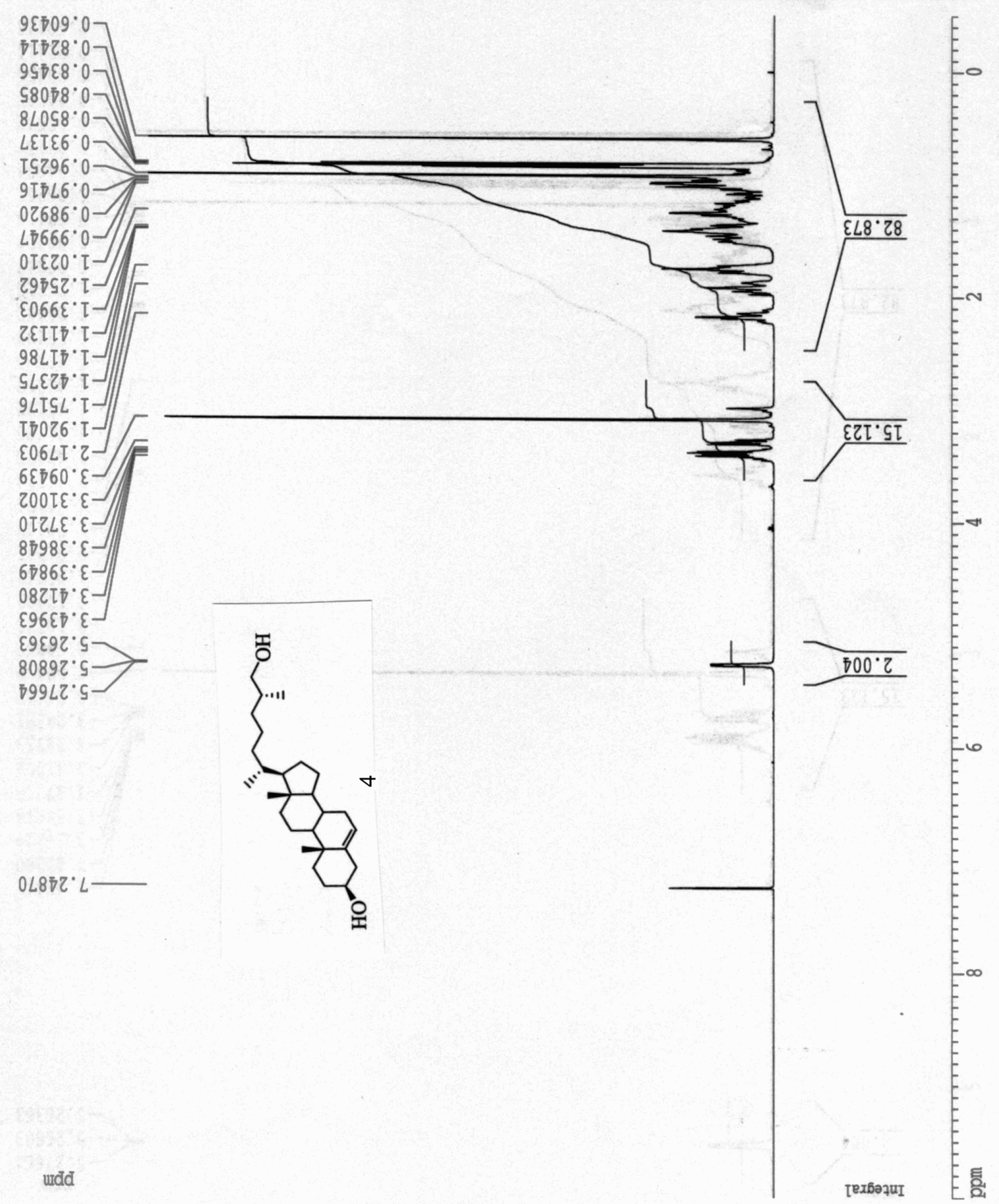




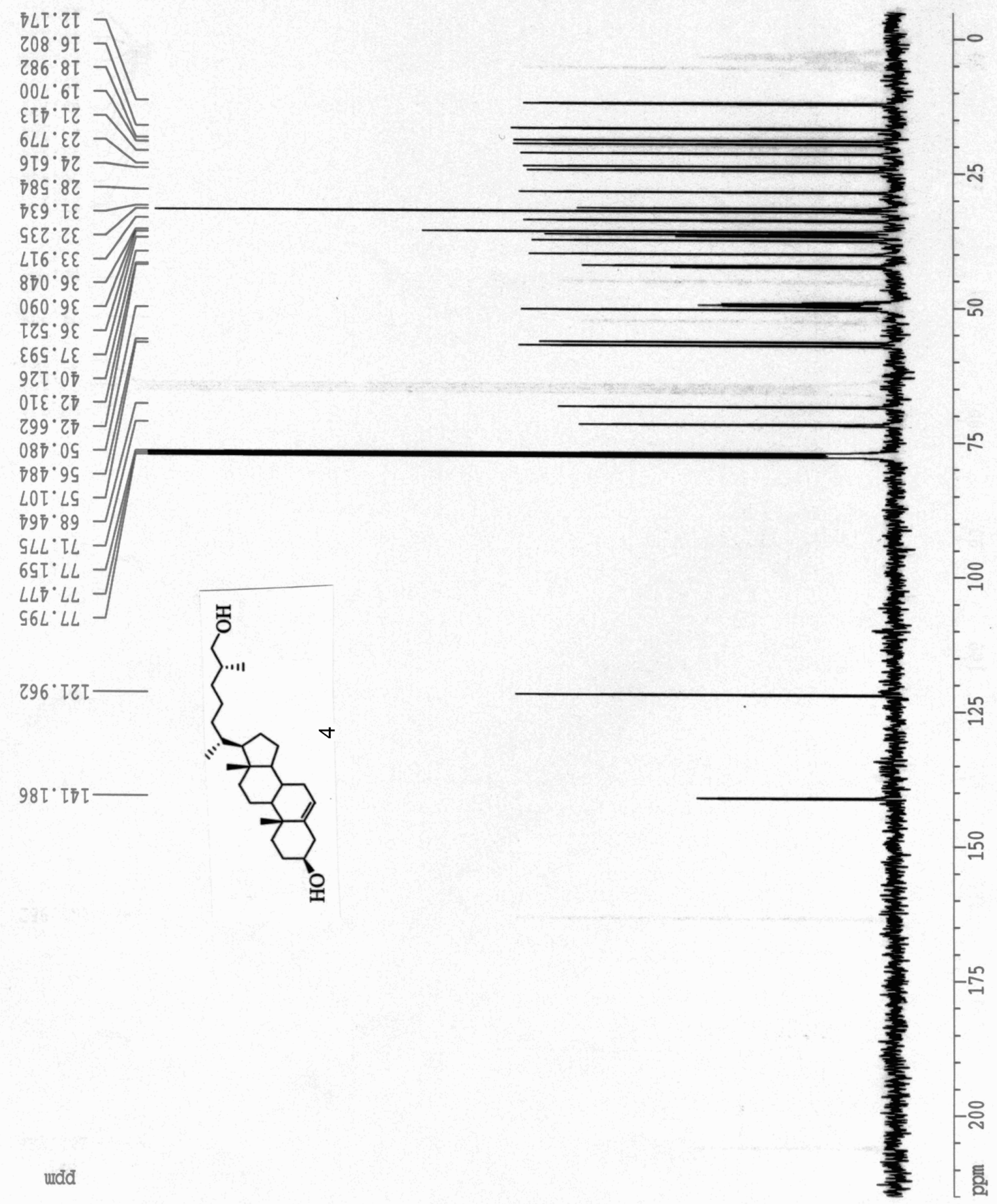




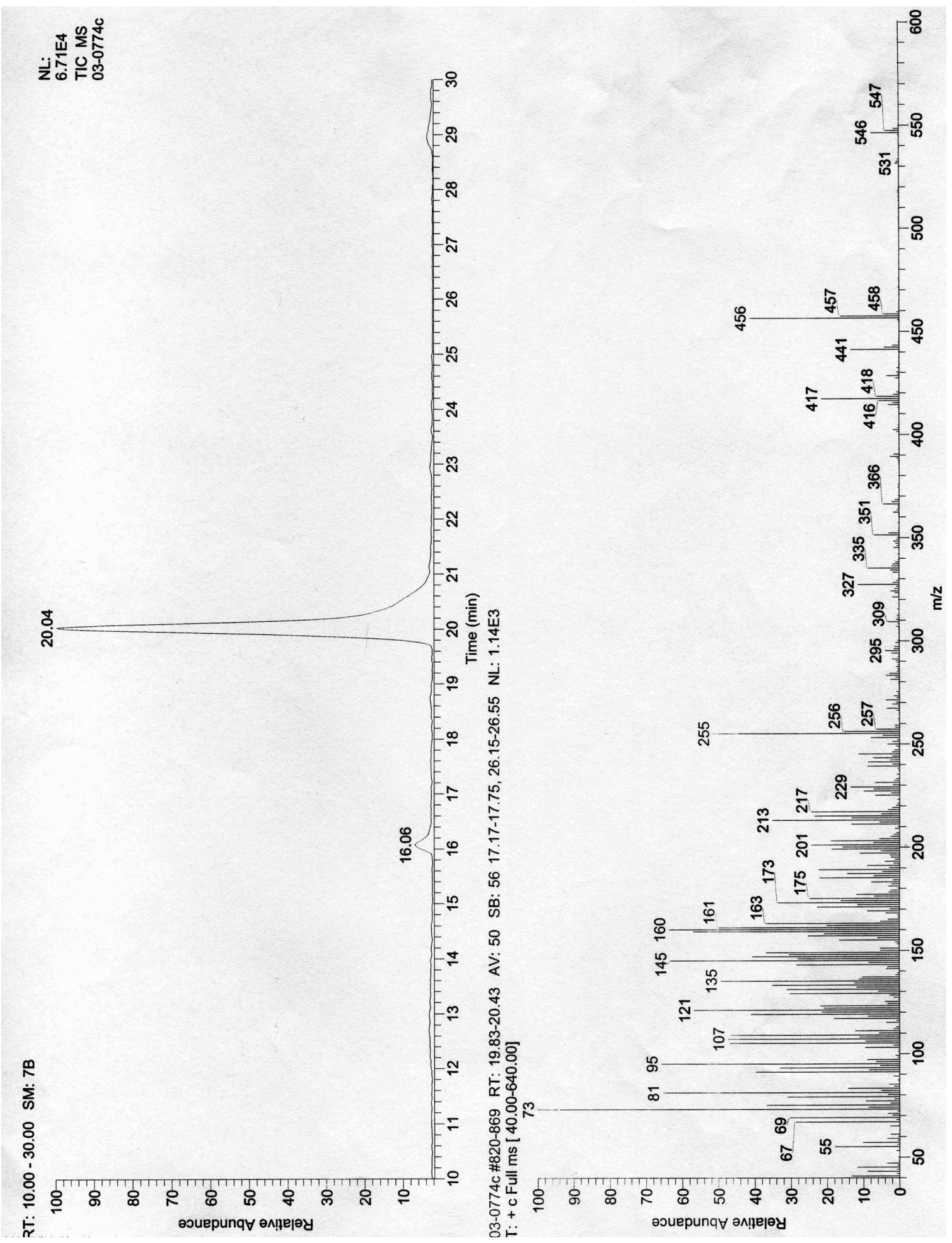




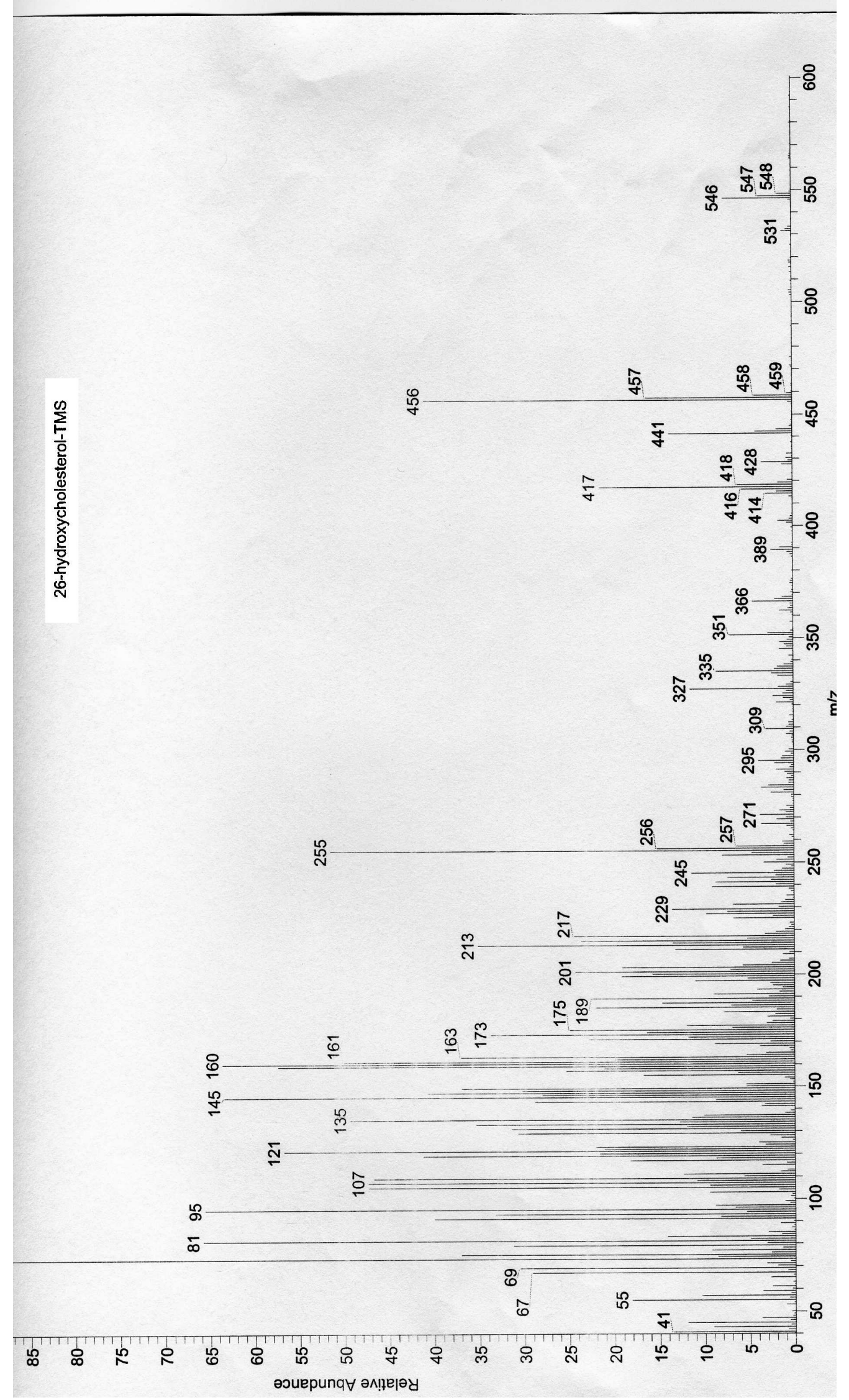




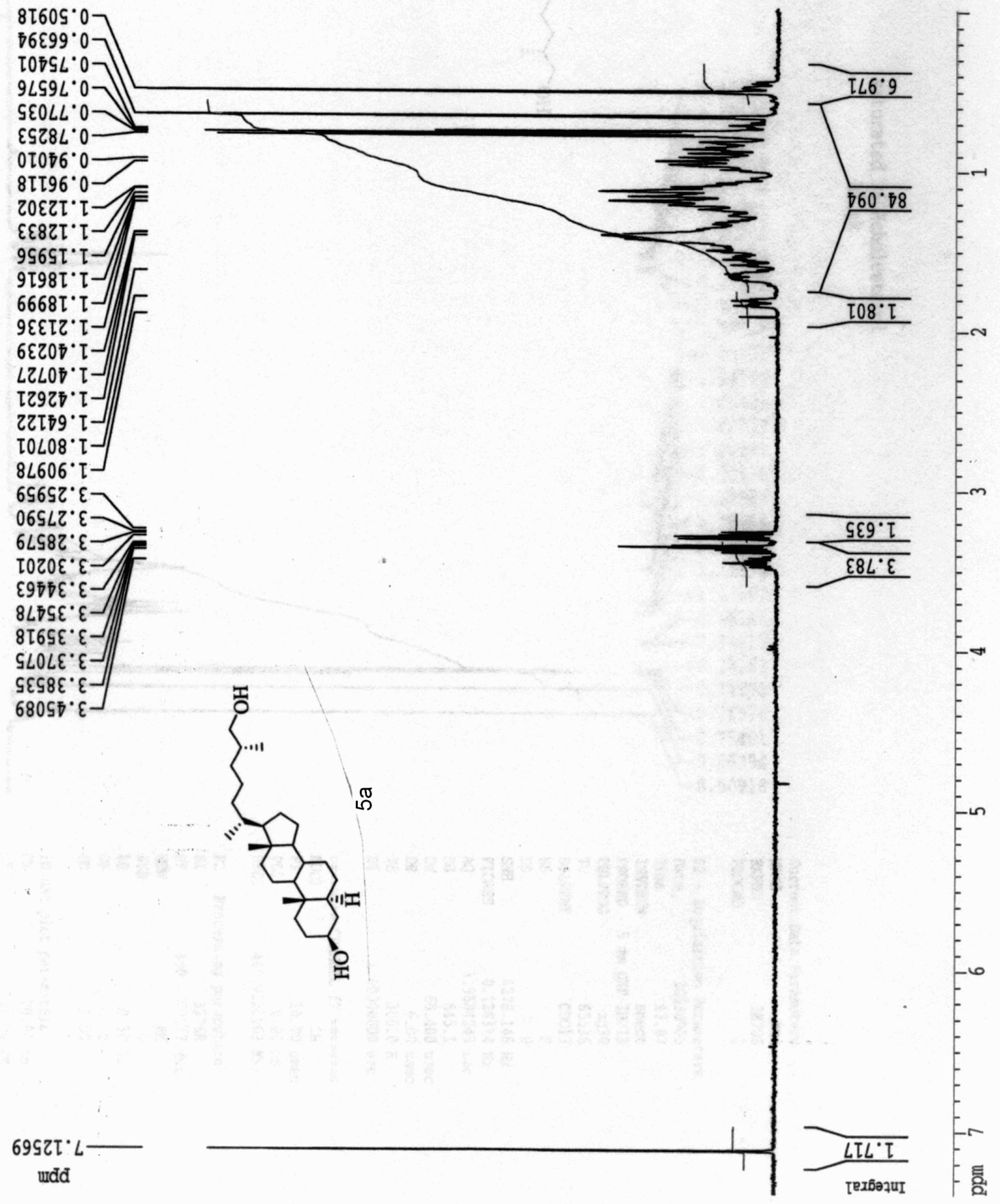




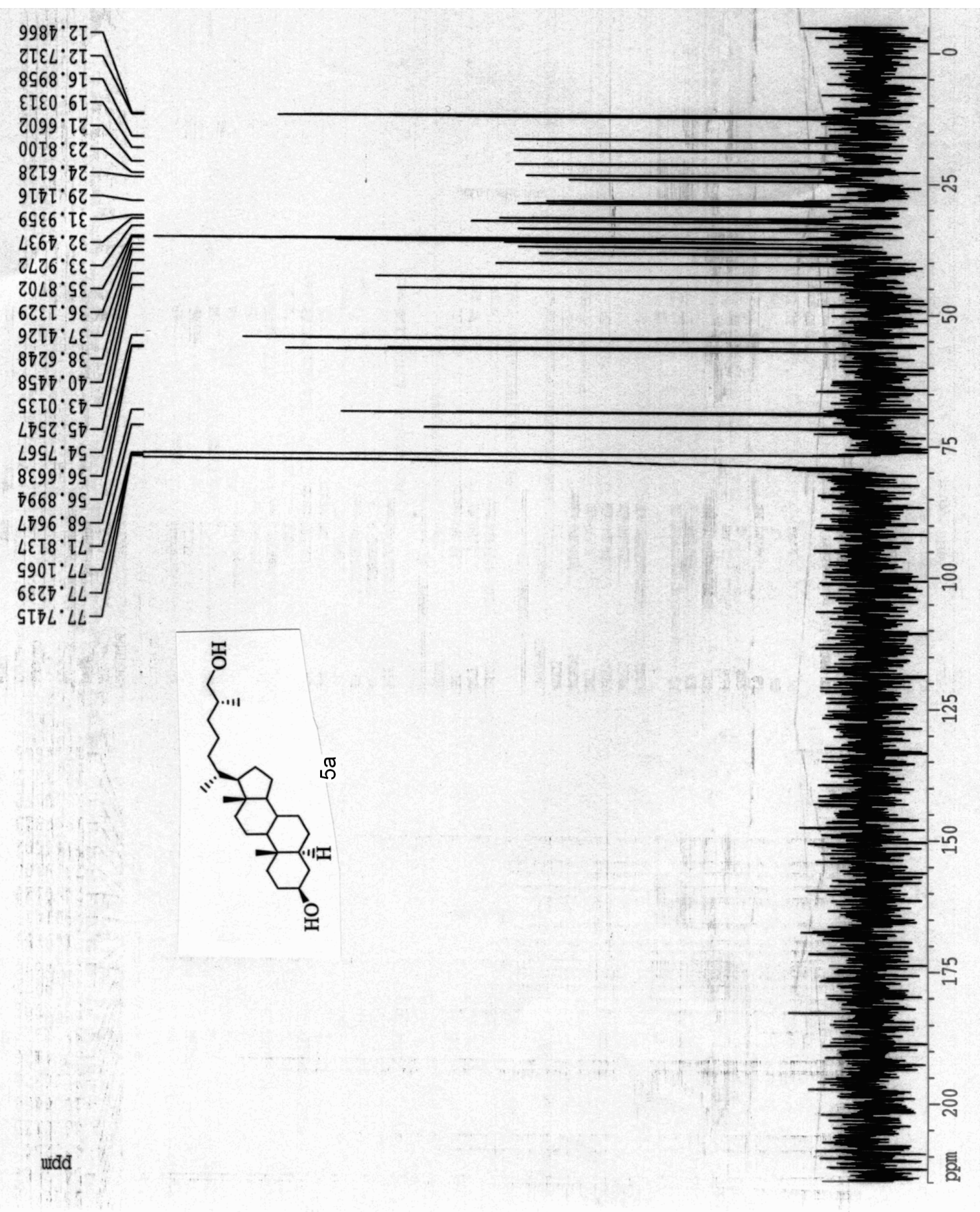




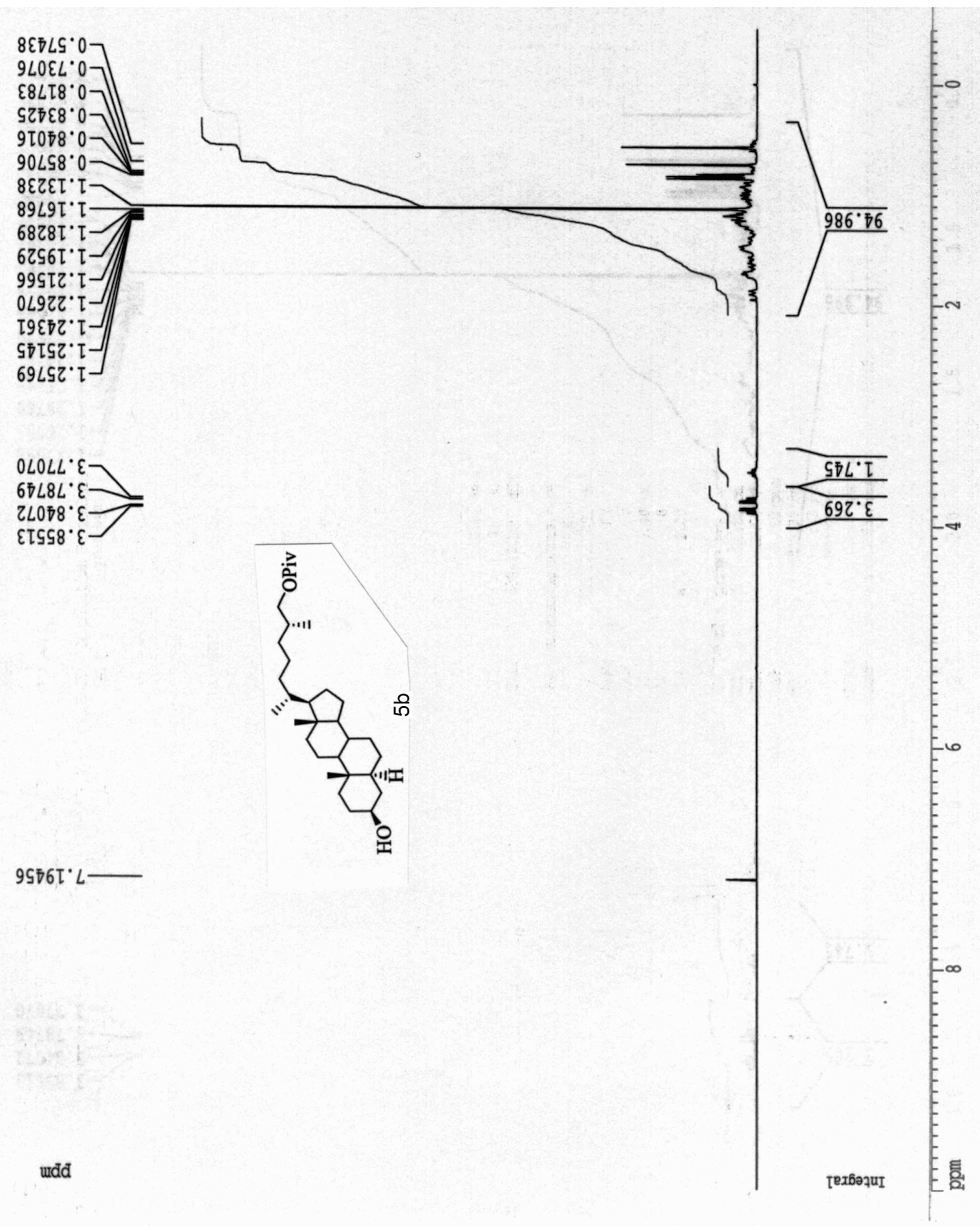




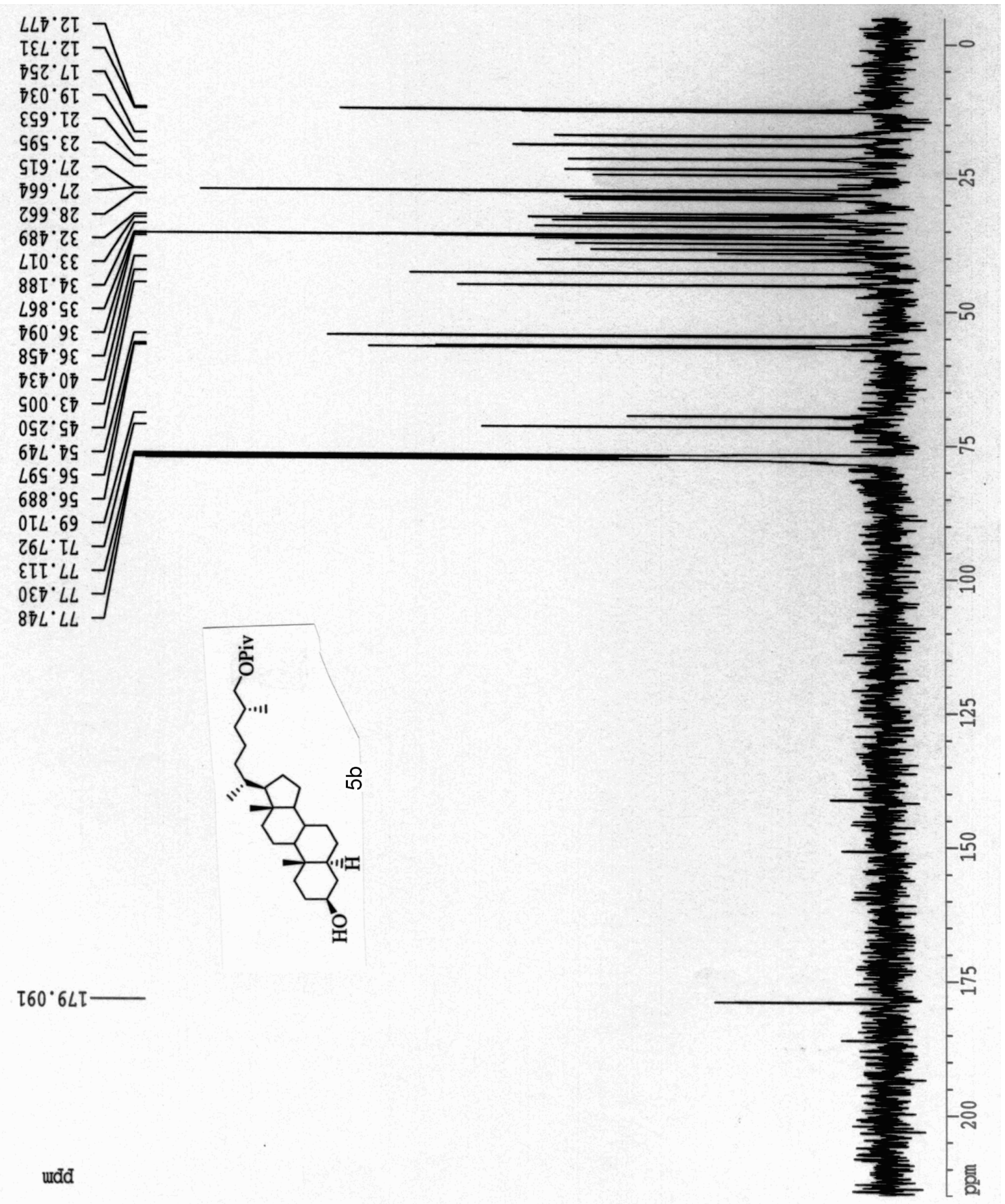




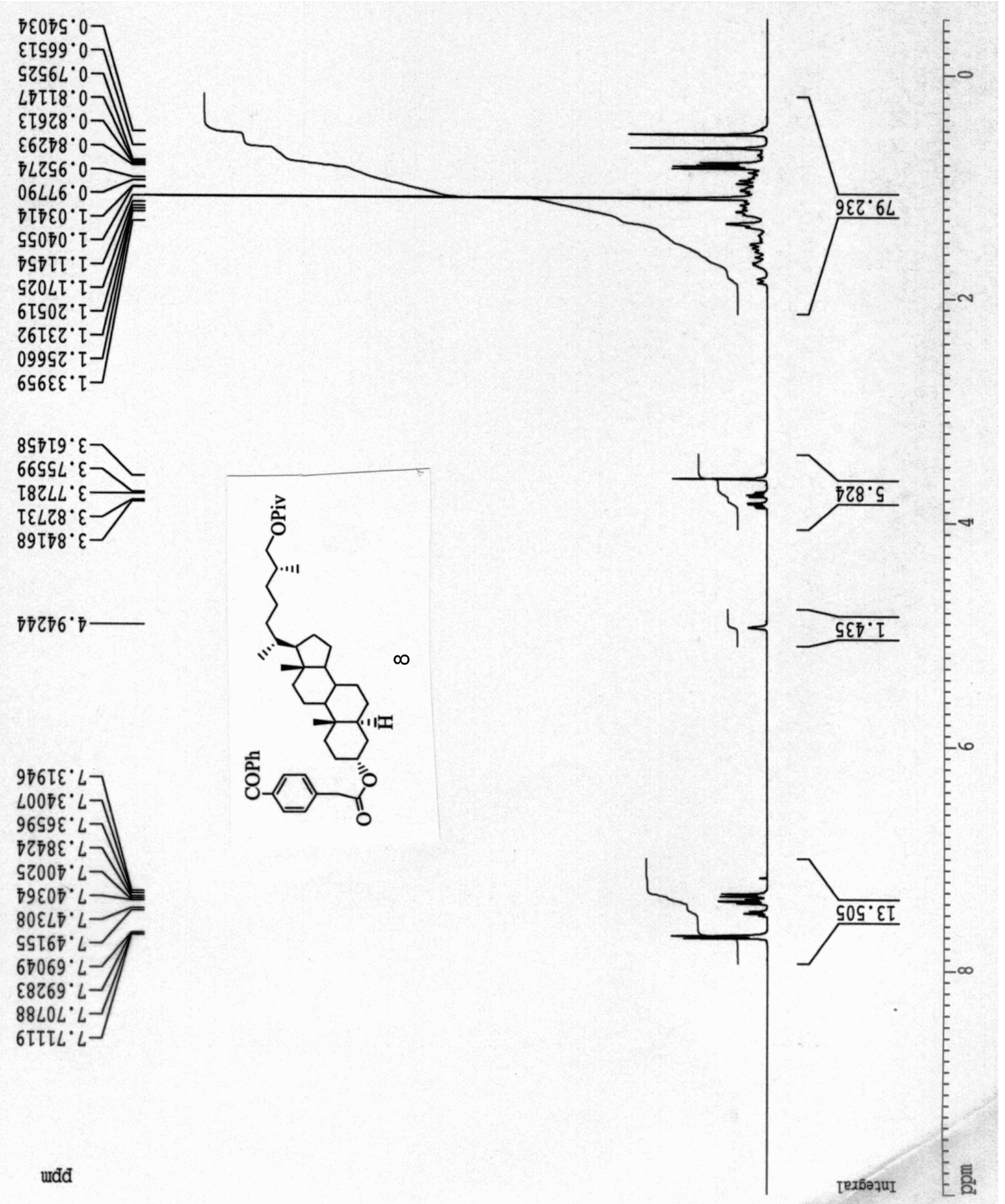




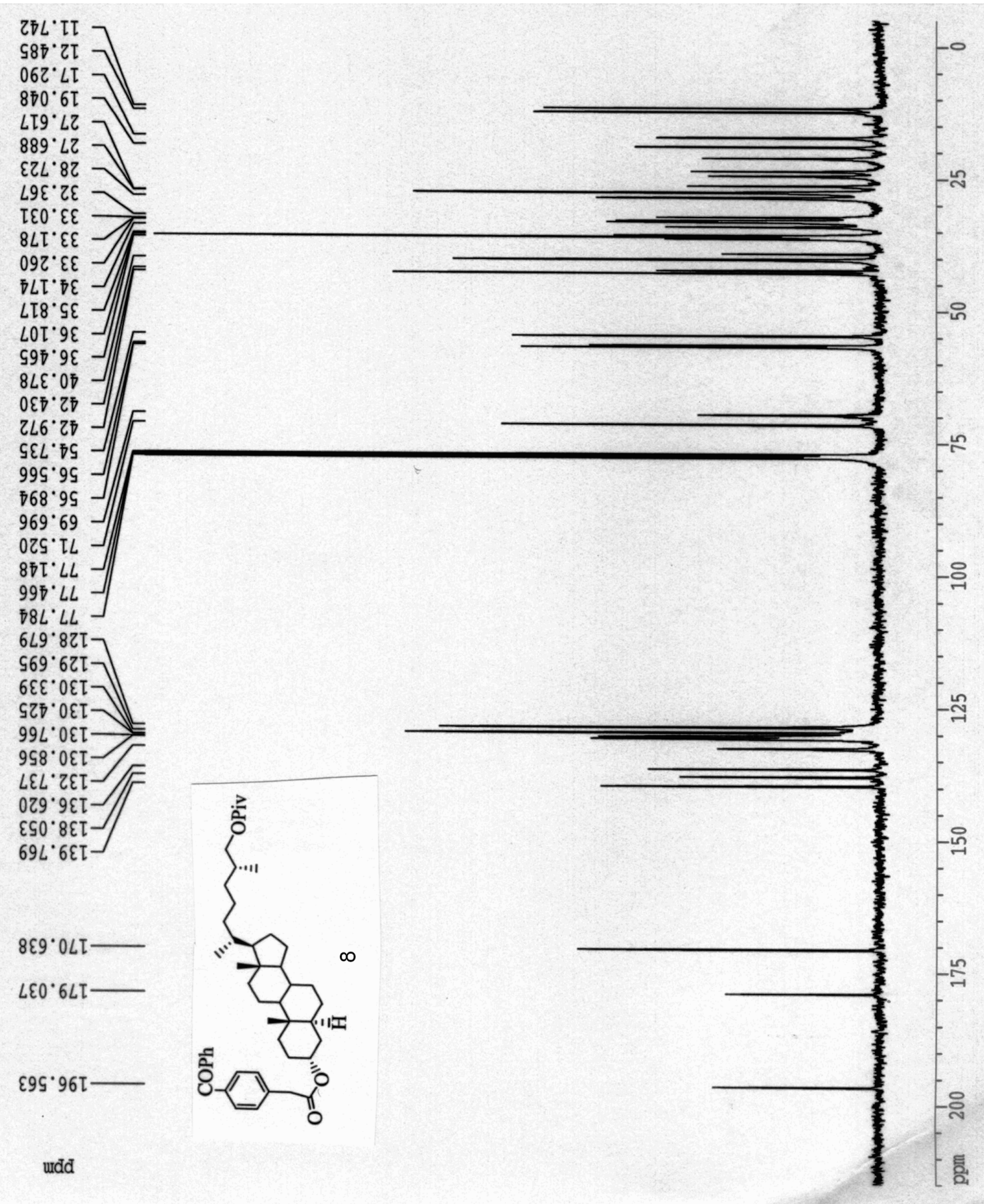




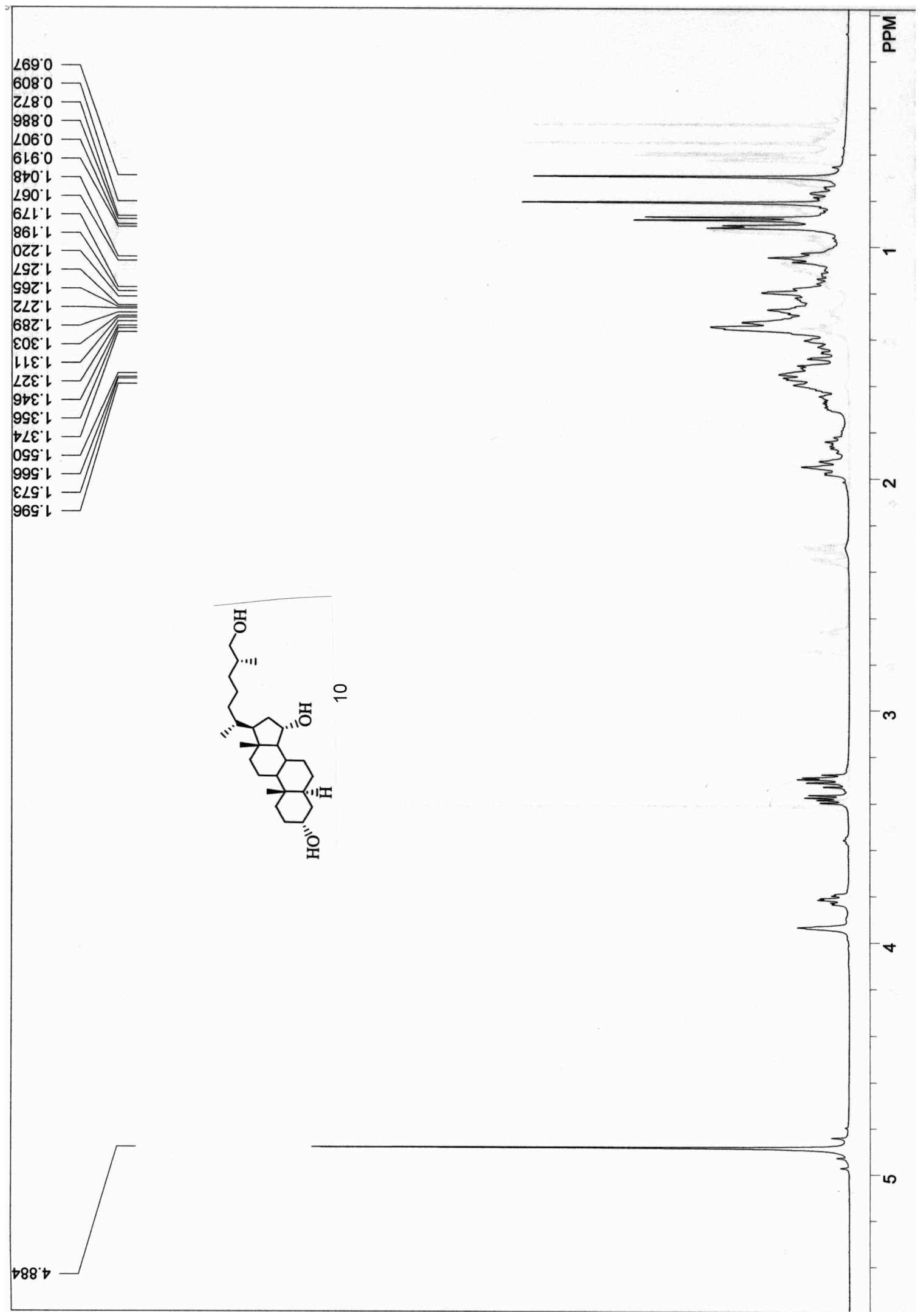




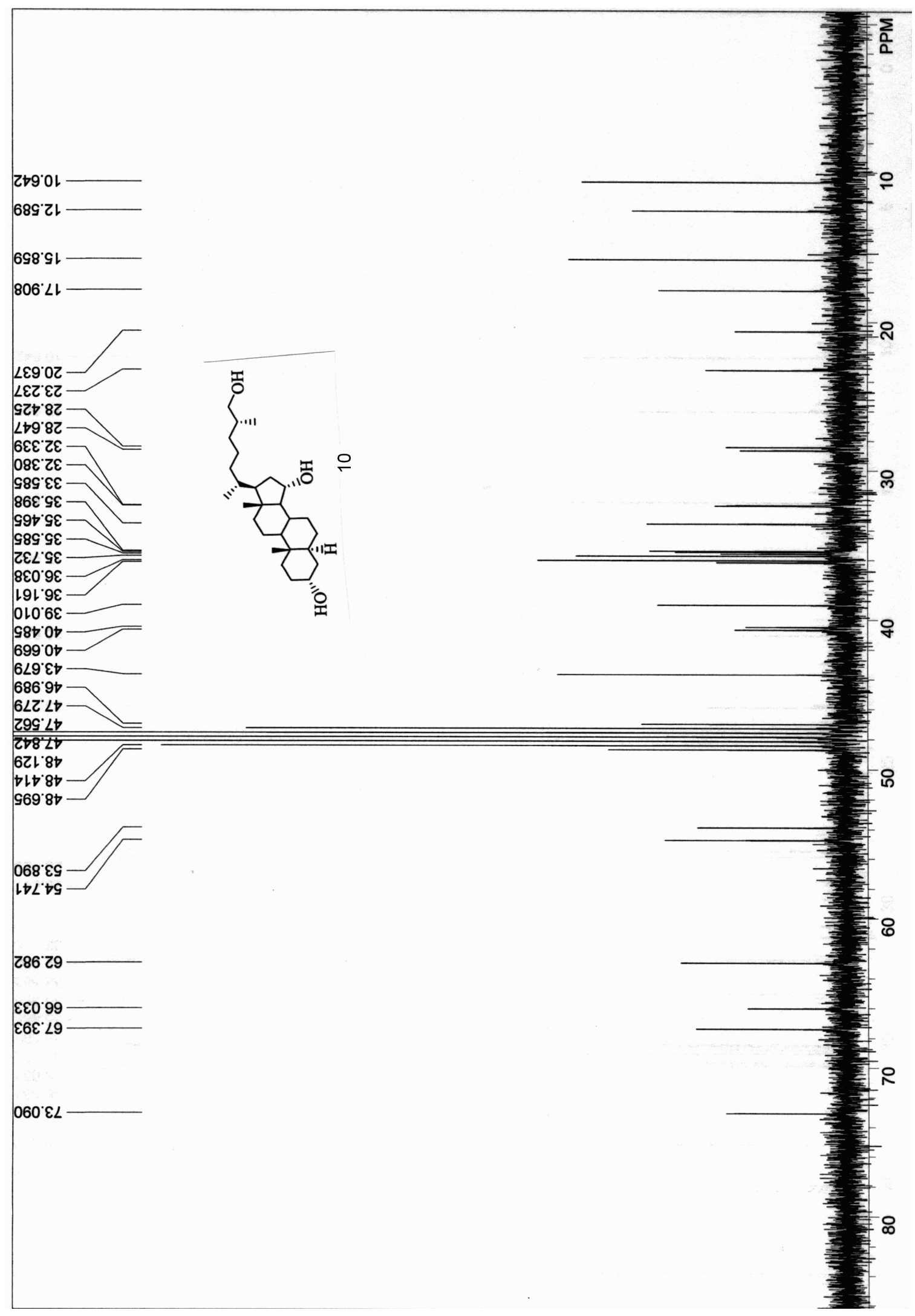




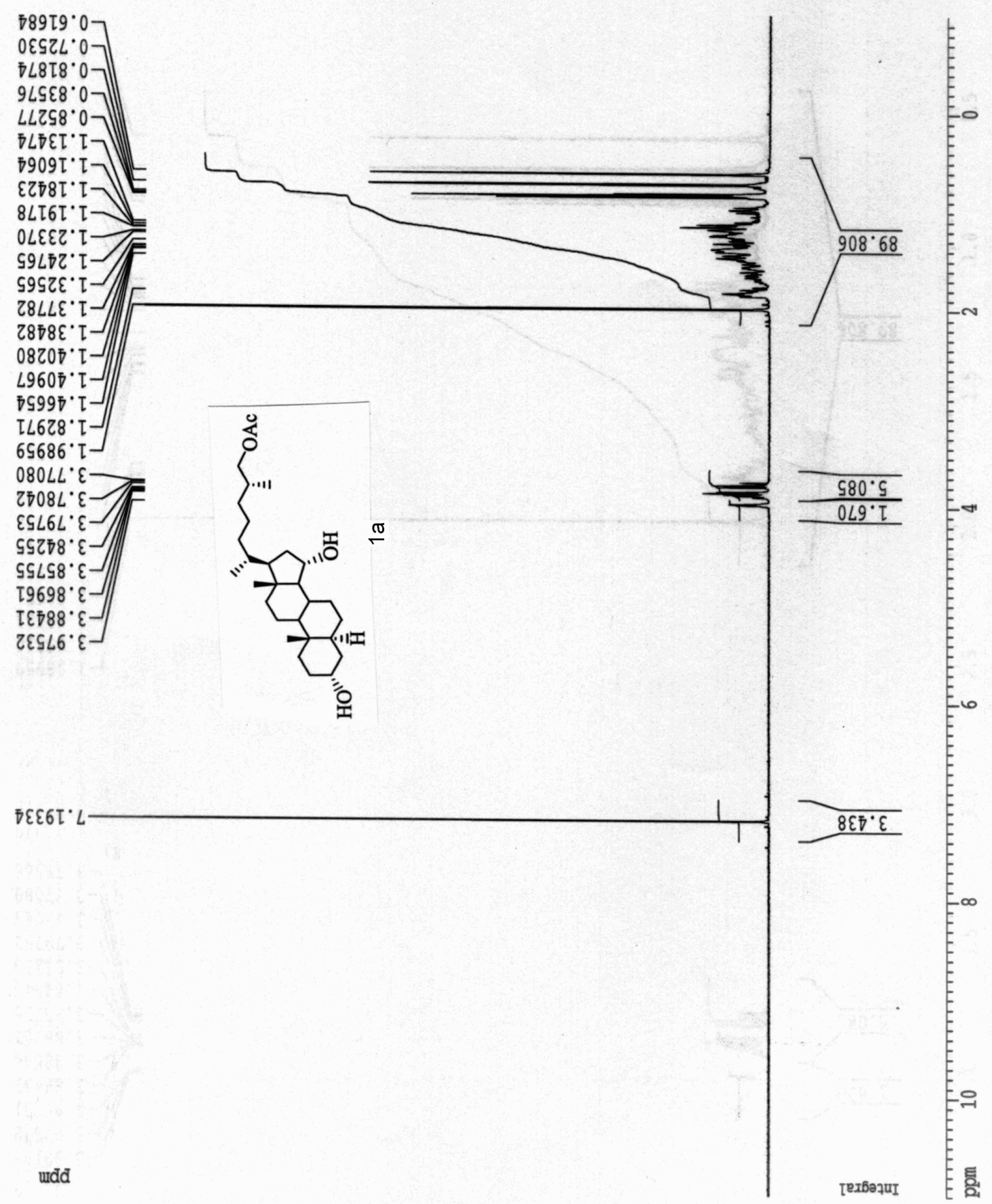




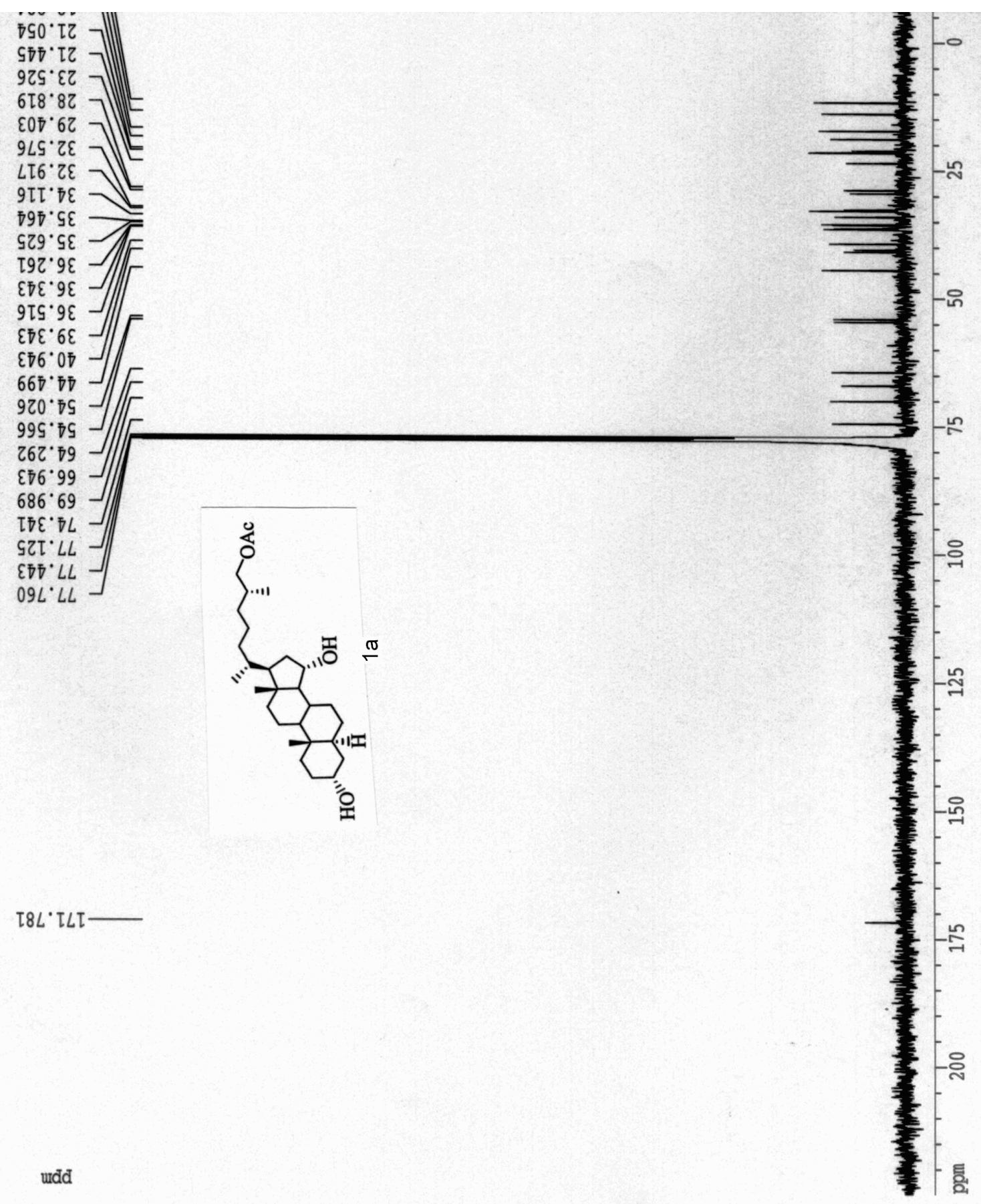

